Turkish Online Journal of Qualitative Inquiry (TOJQI)

Volume 10, Issue 4, October 2019: 511-541

DOI: $10.17569 /$ tojqi. 538428

Research Article

\title{
Contribution of Project-Based Studies to School Culture According to Principals ${ }^{1}$
}

\begin{abstract}
Understanding the actions that affect and form the presence of the organizations is important in understanding the organization itself. The purpose of this research is to determine the place and importance of project-based studies in the formation of school culture from the perspective of principals. Qualitative research method and phenomenological design were conducted in the study. Eleven principals participated in the research. Criterion sampling and convenience sampling among the purposeful sampling strategies were used in order to determine the participants. The data were obtained through the interviews and observations. The data triangulation, comprehensive field survey, external audit, and direct citation strategies were utilized for the validity-reliability aspect of the study. As a result of the research, it was observed that four themes, twelve categories, and twenty-eight subcategories emerged. Based on the data, it is comprehended that four themes existed. These are: School culture, creation of school culture, project-based studies, and project-school culture relationship. As a result of the research, it is concluded that the school culture and projects are important in providing a suitable environment for educational activities in school and in implementing a certain organization. It is also understood that the project-based studies display a proximodistal characteristic. In addition, it is observed that there are various gains from the projects. Some recommendations are given in the last part of the research.
\end{abstract}

Keywords: School culture, project-based studies, principal, qualitative research.

\footnotetext{
${ }^{1}$ This study was presented in oral presentation at the 13th International Congress on Educational Administration held in Sivas-Turkey on May 10-12, 2018

${ }^{2}$ Asst.Prof.Dr., İstanbul University-Cerrahpaşa, Hasan Ali Yücel Faculty of Education, Department of Educational Sciences, abdullah.balikci@ istanbul.edu.tr, https://orcid.org/0000-0002-9824-0197

${ }^{3}$ Prof.Dr., İstanbul University-Cerrahpaşa, Hasan Ali Yücel Faculty of Education, Department of Educational Sciences, ekilic@istanbul.edu.tr, https://orcid.org/0000-0002-6751-9259
}

Received: 11.03.2019, Accepted: 27.10.2019 


\title{
Okul Müdürlerine Göre Proje Tabanlı Çalışmalarının Okul Kültürüne Katkısı
}

\begin{abstract}
$\ddot{O} z$
Örgütlerin yaşamını etkileyen ve yaşamalarına biçim veren eylemlerin anlaşılması, örgütü anlama noktasında önemlidir. Araştırmanın amacı, okul müdürlerinin perspektifinden okul kültürünün oluşumunda proje tabanlı çalışmaların yerini ve önemini tespit etmektir. Araştırmada nitel araştırma yöntemi ve fenomenolojik desen kullanılmıştır. Araştırmaya on bir okul müdürü katılmıştır. Katılımcılar belirlenirken amaçlı örnekleme stratejilerinden ölçüt örnekleme ve kolay ulaşılabilir durum örneklemesinden yararlanılmıştır. Veriler görüşmeler ve gözlemler yoluyla elde edilmiştir. Araştırmanın geçerlik-güvenirlik aşamasında veri çeşitlemesi, kapsamlı alan çalışması, dış denetim ve doğrudan alıntı stratejilerinden yararlanılmıştır. Araştırma sonucunda dört temanın, on iki kategorinin ve yirmi sekiz alt kategorinin ortaya çıktığı anlaşılmıştır. Araştırmada verilerden hareketle dört temanın ortaya çıktığı anlaşılmaktadır. Bunlar: Okul kültürü, okul kültürü oluşturulması, proje tabanlı çalışmalar ve proje-okul kültürü ilişkisidir. Araştırma sonucunda, okul kültürünün ve projelerin okulda eğitim öğretim faaliyetlerinde uygun bir ortamın sağlanması ve belli bir düzenin hayata geçirilmesi adına önemsendiği anlaşılmaktadır. Proje tabanlı çalışmaların yakından uzağa bir özellik gösterdiği anlaşılmaktadır. Projelerden çeşitli kazanımların olduğu görülmektedir. Araştırmanın son bölümünde önerilere yer verilmiştir.
\end{abstract}

Anahtar Sözcükler: Okul kültürü, proje tabanlı çalışmalar, okul müdürü, nitel araştırma. 


\section{Introduction}

Understanding the actions that affect and form the presence of the organizations is important in understanding the organization itself. One of the points that should be taken into consideration in understanding the organizations is the culture that exists in the organization. According to Turkish Language Institution (TLI, 2019), culture is a concept that has different meanings such as "knowledge gained by the individual; the form of reasoning, pleasure and criticism skills developed through learning and experiences". According to Hoy and Miskel (2010, p. 167), it is "shared values and beliefs".

It is possible to mention about the various dimensions and forms of culture. Organizational culture is also mentioned in the literature as one of them. Organizational culture, according to Hoy and Miskel (2010, p. 165), is "a system of shared orientations that hold units together and give them a distinctive identity". According to TLI (2019), it is "a set of changeable values, thoughts, and rules that form the behavior of the staff and the general appearance of the place of work, which can be learned and taught through symbols, transferred from generation to generation, and can be changed". Understanding the contribution of organizational culture in terms of performing its functions in the organization will help to perceive the relationship between organization and culture. According to Şişman (2002), organizational culture can be perceived as an instrument for organizational integration, motivation, productivity, effectiveness, performance, control, coordination, communication, socialization, and problem solving. Therefore, organizational culture can be considered as one of the important factors forming the organizational structure. According to Cameron and Quinn (2017), organizational culture is;

$\checkmark$ It provides organizational administrators with the opportunity to increase their effectiveness thanks to its conceptual and scientific aspects.

$\checkmark$ It gives ideas about how the things work in the organization.

$\checkmark$ It presents a sense of identity.

$\checkmark$ It helps to balance the unwritten and unspoken principles and experiences.

In this context, the organizational culture is;

$\checkmark$ Practical.

$\checkmark$ Effective.

$\checkmark$ Inclusive. 
$\checkmark$ Both qualitative and quantitative.

$\checkmark$ Manageable.

$\checkmark$ Valid.

According to Hindle (2014), the behaviors of employees (which are in the form of peer learning), the process of staff selection (employing appropriate staff of organizations to their own culture), the nature of work (the existence of a work-specific culture), and the external environment (the society in which the organization continues to exist). It is observed that what refers to the organizational culture is a strong and healthy culture in the related literature. In the context of organizational culture, the school culture also has its own characteristics. These are:

Being goal-oriented,

$>$ Including codetermination,

$>$ Being open to innovation,

$>$ Leadership,

$>$ Cooperation among the teachers (Engels, Hotton, Devos, Bouckenooghe and Aelterman, 2008; cited by Bayrakc1, 2014)

The school administrator has an important function in the formation of the school culture and its existence in accordance with its purpose. According to McEwan (2018), an effective school administrator should pay attention to certain points in building school culture. These can be listed as:

- The school administrator perceives the importance of culture and values to it.

- The school administrator is aware of what a culture is.

- The school administrator contributes to the development of the core values of culture.

- The school administrator knows those who contribute to the core values of the culture and rewards and appreciates them when appropriate.

- The school administrator cares about the needs and interests of people in terms of culture.

- The school administrator is aware of the huge contribution of small culture-related things to the school.

Whereas Hofstede (1990) defines the role of administrator in organizational culture as to establish a connection between subordinates, Schein (1984) determines this task as to contribute to the survival of culture in keeping with change. Westhuizen, Mosoge, Swanepoel, 
and Coetsee (2005) emphasize that the school administrators attach importance to their stakeholders in organizational culture. Stakeholder contribution to the school culture will help the school administrator better manage the school. Deal and Peterson (1990) state that the implementation of the stated mentality by the administrator will contribute to the effective conduct of student-centered studies by the student. Fourie (2018) describes the role of principal in the school as making a learning-teaching centered culture dominant by making the attitudes of teachers towards school positive and improving their performance. Wagner, Harrison and Vogel (2016) emphasize on what the school administrators do for students in terms of positive effect on school culture. These are the studies related to academic achievement of the students and development of learning environments as well as the social activities supporting these studies. Çevik and Köse (2017) mention that there should be a healthy communication and cooperation between the teachers and the principal so as to create a school culture as stated. Similarly, Renchler (1992) states that an understanding of school administration based on open communication and cooperation in school culture will bring success.

Many different studies on the connection between school, school culture, and school administration were found in the literature. Ketterlin-Geller, Baumer, and Lichon (2015) state that the presence of meaningful communication will contribute to school culture. School culture can be transferred to the student through organized and special programs. In order to do this, the school administrator needs to be aware of the necessity of a suitable environment in the school environment and create the environment. The purpose is to realize a culture that can contribute to the education of successful students. A study carried out by Mees (2008) indicates that there is a positive relationship between the attitudes of the principals and student achievement. In his study, Savory (2014) stated that there is an understanding of development in a successful school culture and that the school administrator has an important effect on the creation of culture in the desired direction around the school. Şimşek (2003), on the other hand, suggests that the principals should have communication skills in order to achieve the desired effect in school culture. The research by Kraft, Marinell, and Shen-Wei Yee (2016) shows that the attitude of school administrators towards teachers is decisive for effective school culture, and that the more developed the school culture is, the better the performance of teachers is at school. 
Different studies are carried out in schools to create and develop school culture. One of them is projects. Many benefits are expected from long-term projects. According to TLI (2019), the project is a scientific study task that has been previously planned and programmed in different fields, the cost of which has been calculated, approved by the governing bodies of the institutions and organizations, and accepted to be carried out on behalf of the private institution or the government by designing them in terms of the short and long term. As it can be understood from the definition, the project is accepted by the parties in the short or long term and is considered to bring benefits to the project parties. When the related literature is examined, it is understood that the project studies have positive effects. Ak1ll (2017) lists these effects as follows: These are to gain work experience, to develop cooperation environment with students and teachers, to help the understanding of the scientific method, and to contribute to looking at the events from a different perspective. It is revealed that the project studies affect the emotions of students and that these emotions are generally positive (joy, enthusiasm, etc.). Kocaarslan (2010) states that the project tasks are beneficial in terms of gaining the habit of working together, sense of responsibility, and problem solving habit among the students. According to Börekci (2018), project-based studies improve the cognitive skills of students. In addition, such studies increase the interaction among students and lead to increased motivation in the classroom. Therefore, it contributes to the further implementation of what is learned and to project-based studies at school. The study by Karakuş (2004) has similar results. According to the research, the project-based approach has a positive effect on the lives of students both in and out of school and especially on their problem solving skills. The projects can have positive effects on such psychological levels of the project team as communication and motivation. Zelyurt (2011) reveals that the project training taken by the teachers for a school culture based on project studies will have a positive effect on project studies. The same research shows that the teachers are eager to receive training on project studies and that the training will facilitate the management of the projects. However, according to Karadeniz (2012), in the project studies to be carried out, the project managers are expected to assist and support the project team, and they are also expected to balance the effects of adverse situations (constraints, resource shortages, etc.).

It can also be stated that there are items in the Turkish Education System that are expected to contribute to the school culture. These are shown in Table 1. 
Table 1

Items related to Project Studies*

\begin{tabular}{clc}
\hline $\begin{array}{c}\text { Item } \\
\text { Number }\end{array}$ & \multicolumn{1}{c}{ Legal Basis } & Related Item Number \\
\hline 1 & Constitution & 42 \\
\hline 2 & Basic Law of National Education & $4,11,13,34,35,43$ \\
\hline 3 & $\begin{array}{l}\text { Regulation on Preschool Education and Primary } \\
\text { Education Institutions of Ministry of National Education }\end{array}$ & 7 \\
\hline 4 & $\begin{array}{l}\text { Regulation on Social Activities in Educational } \\
\text { Institutions of Ministry of National Education }\end{array}$ & $4,5,7,161$ \\
\hline 5 & $\begin{array}{l}\text { Regulation on Secondary Education Institutions of } \\
\text { Ministry of National Education }\end{array}$ & \\
\hline
\end{tabular}

*These were taken on 06.02.2019 from the links below

http://www.meb.gov.tr/mevzuat/liste.php?ara=12, http://www.meb.gov.tr/mevzuat/liste.php?ara=2,

http://www.meb.gov.tr/mevzuat/liste.php?ara=6

Initially, CHE (Council of Higher Education) thesis bank was searched for this study. A total of 492 theses (420 for MA and 72 for $\mathrm{PhD}$ ) have been searched in the field of related education and training. In addition, the researches which are thought to be similar to the research topic have been examined in journals in various indexes related to the research topic. In the theses and journals, it has been observed that the current research has not been sufficiently investigated both in terms of subject and method. Although the researches revealed the construction of the projects, the things carried out through the project and the school culture, the problems encountered, and the thoughts related to them, it was observed that its connection with the school administration and the principals in particular was not examined sufficiently. The quantitative research method was generally preferred as the research method in these studies mentioned above. All these points make the researchers think that the preferred subject and method will contribute to the field.

\section{Purpose of the Research}

The purpose of the research is to determine the place and importance of project-based studies in the formation of school culture from the perspective of principals. For this purpose, the following questions were sought: 
1. According to the school administrators, what is happening in the formation process of school culture?

2. According to school administrators, how is the school culture-project interaction?

\section{Method}

In this section, the studies about the method of the research are explained in detail.

\section{Research Method and Design}

The qualitative research method was preferred in this study. As a reason of preference, qualitative research can be stated to allow the participants to express their opinions comprehensively and clearly and thus to make meaning from the mentioned opinions in line with the research, and to exclude the meanings that are not related to the research. In addition, the experience of the researchers as a school administrator and teacher was effective in the choice of method. These justifications are reflected in the views of Creswell (2016) on how to conduct qualitative research. According to the author, what is important in qualitative research is to spend enough time in the field, to reveal the perspective of participants and to be flexible in the research process. Phenomenology was preferred as the research design. The reason for this preference is the willingness of the participants to present their experiences and their explanations based on their experiences, as can be seen from the quotations in the findings. In addition, as the interviews were conducted and analyzed, it was found that the level of contribution to the research was high and that the design was suitable for the research. According to Christensen, Johnson, and Turner (2015), the phenomenological design is based on how the participants experience and make sense of a phenomenon.

\section{Participants}

The participants of the research consist of eleven principals who try to create a school culture based on the projects they have carried out, can transfer their experiences and participate voluntarily in the research. Two of the participants were female, and nine of them were male, and they still work in state schools. The eleven principals include two pre-school principals, 
four primary school principals, four secondary school principals, and one secondary school principals. The distribution of the participants according to their branches was as follows: four participants as classroom teacher, two participants as preschool teacher, one participant as Turkish language and literature, mathematics teacher, social studies, religious culture and ethics teacher, and physical education teacher. The seniority of the participants ranges from 8 to 32 years, and the seniority of administration varies between 2 and 32 years. The fact that the researchers had school administration and teaching experiences was also effective in determining the participants. The fact that the researchers have the opportunity to meet with principals in formal and informal meetings and interviews and know whether they have made projects or what kind of projects they have done is thought to contribute to both determining the group of participants of the research and analyzing and interpreting the research data. As stated in the research, since the principals who have made projects were included, the criterion sampling from purposeful sampling methods was used. Volunteering was the basis for the determination of the participants. The views of the participants are not presented by using their real names but using code names. The coding is made as P1, P2, or etc. According to Miles and Huberman (2015, p. 28), criterion sampling is "all situations that meet the same criteria and assist in quality assurance". In addition to criterion sampling, convenience sampling was also used since the opinions of principals who were encountered in formal and informal meetings and were invited were utilized. According to Miles and Huberman (2015, p. 28), convenience sampling provides "time, money, and flexibility savings at the expense of information and reliability". Maximum variation sampling was also used in the study since there were participants from different school types. According to Miles and Huberman (2015, p. 28), maximum variation sampling is "to document different varieties and to identify important general patterns". In the study, it was not considered necessary to increase the sample size by considering that the data obtained from eleven principals were sufficient to describe, comment, and draw conclusions. In the literature, there is no mention of a certain number and size for sampling size, and the data are taken into consideration (Patton, 2014; Merriam, 2015a).

\section{Data Collection}

The data sources in the research are the interviews and observations. A semi-structured interview form was generated for the interviews. In the preparation of the interview form, the 
relevant literature was first reviewed, and then an interview was carried out with two school administrators who were planned to be interviewed and thought to contribute to the research. In addition, the research topic was discussed with two academicians studying in the field of educational management and having conducted qualitative research before. Afterwards, the interview form was piloted with two participants. As a result of the pilot practice, it was presented to the opinion of two academicians, and feedback was provided that the answers would contribute to the research and that no change in the interview form was required. In addition, the interview form was presented to the examination of two Turkish Language and Literature experts in terms of language and expression, and the feedback form was taken as appropriate. After the mentioned stages, interviews were conducted with nine principals. The interviews lasted a total of 360 minutes and 52 seconds, with an average of 33 minutes and 18 seconds for each participant. 13 main questions and 16 probe questions were asked in the interview form. The questions are based on the experiences of the principal and their understanding of school culture perceptions and activities, the projects carried out and the effects of these projects, and finally the school culture-project interaction. 10 of the questions were related to the research topic, and the other 3 questions address the methods, permissions, and situations that are expected to be included in the research. Besides the main questions, the probe questions were also used at the interview. According to Merriam (2015b), the probe questions are directed to explanations aimed at accessing more information. The second source of data is the observations of the researchers. Two points were considered in the observations. The first one is the observations that the researchers have while working as teachers and school administrators. The second one is the observations made by taking the issues mentioned by Merriam (2015c) into consideration. The observations were made before, during, and after the interviews in the schools where the participants worked. The subjects to be observed were transformed into a form based on the source specified by the researcher and used in the research. The opinions of the researchers about the participants, the attitudes towards the participants, the practices carried out for the mentioned opinions, the environment, and the remarkable points that can contribute to the research are included in the form. The data obtained are stated in the findings section. 


\section{Data Analysis}

The data were recorded by using the voice recorder, and the recordings were documented. After the documentation step, the written form of the interviews were sent to the participants, and then the analysis phase was started after their approval. According to Glesne (2015), data analysis is a study of establishing order and creating a meaningful whole for the research data. Open coding was used in the data analysis. The reflection of the open coding to the research was the re-reading of the transcripts, revealing the relationship between the data, and reaching the category and the latest themes based on the relationships. This coding-based study is shown in Table 2. According to Neuman (2010), open coding is the first coding of qualitative data, and the researcher examines the data and summarizes it in preparatory analytical categories or codes. Descriptive analysis technique was also used to analyze the data. According to Y1ldirım and Şimşek (2011), it is essential to include the opinions of the participants in the descriptive analysis. The purpose of giving opinions is to explain the findings regularly by considering the cause and effect relationship into consideration. The implementation of descriptive analysis in the research is to reveal the relationship between the data by means of open coding, to convey the opinions about the research directly, to reveal the meaning of the quotations, and finally to compare the findings with the related literature. Content analysis was performed in the analysis of the data. According to Krippendorff (2004), the important point in content analysis is to derive meanings from the texts according to a certain systematic. In the research, content analysis was tried to be reflected through the themes and categories derived from data (Table 2).

\section{Validity-Reliability Strategies Used in Research}

Four of the strategies stated by Christensen, Johnson and Turner (2015) were used in order to increase the reliability-validity of the research. These strategies were used in the research as follows:

Data Triangulation: The data were collected by applying the semi-structured interview form to eleven school principals and through the observations by the researchers. In the findings section, the data are respectively presented through the direct citations, the experiences of the researchers as teacher and school administrator, and the data obtained from the opinions of 
Merriam (2015c) related to the observations. Observations were made in the schools where the participants were working and in their rooms during the interview.

Comprehensive Field Survey: The literature was reviewed for research, and it was tried to establish the infrastructure for both scientific dimension and interview forms.

External audit: In all stages of the research process, the required evaluations were conducted with two academicians who have done research in the field with qualitative research method, and thus the data that would not contribute to the research were excluded from the research.

Direct Citation: While evaluating the data, the citations obtained through the transcribed data were used, and it was tried to ensure consistency between the comments on the research and the citations.

\section{Ethics in Research}

The interviews were conducted after obtaining the necessary permissions and appointments from the participants in terms of research ethics on an individual and institutional basis. For this purpose, a question requesting permission to publish the research was added to the interview form, and the required approval was obtained from the participants. All these approvals were archived in voice recorder and e-mail setting.

\section{Findings}

Findings obtained from interviews and observations are given in this section.

\section{Findings Obtained from the Interviews}

It is understood that four themes, twelve categories, and twenty-eight sub-categories emerged as a result of the interviews. 
Table 2

Themes and Categories in the Research

\begin{tabular}{|c|c|c|}
\hline \multirow{6}{*}{$\begin{array}{l}\text { 1. Theme: Perception of School } \\
\text { Culture }\end{array}$} & \multirow{2}{*}{ Definition of school culture } & Order \\
\hline & & Environment \\
\hline & \multirow{2}{*}{$\begin{array}{l}\text { Differences in creating school } \\
\text { culture }\end{array}$} & Working style \\
\hline & & Conditions \\
\hline & \multirow[t]{2}{*}{ Characteristics of school culture } & Values \\
\hline & & Communication \\
\hline \multirow{11}{*}{ 2. Theme: Creating School Culture } & \multirow{4}{*}{ Continuous studies } & Communication with parents \\
\hline & & Organizing meetings \\
\hline & & Providing appropriate environment \\
\hline & & Being role model \\
\hline & \multirow{3}{*}{ Highlights } & Being empathetic \\
\hline & & Behaviors of administrators \\
\hline & & Supportive approach \\
\hline & \multirow{2}{*}{ Attitudes of employees } & Positive attitude \\
\hline & & Negative attitude \\
\hline & \multirow{2}{*}{ Facilitating and difficult factors } & Parent \\
\hline & & Habits \\
\hline \multirow{8}{*}{ 3. Theme: Project-Based Studies } & \multirow{2}{*}{ Projects } & Process \\
\hline & & Content \\
\hline & \multirow{4}{*}{ Objectives in Projects } & Correcting negative behaviors \\
\hline & & The need for project studies \\
\hline & & Active participation in studies \\
\hline & & Gaining values \\
\hline & \multirow[t]{2}{*}{ Evaluation of Projects } & Emotional effect \\
\hline & & Contribution to school culture \\
\hline \multirow{3}{*}{$\begin{array}{l}\text { 4. Theme: Project-School Culture } \\
\text { Relationship }\end{array}$} & $\begin{array}{l}\text { Reflections of projects on school } \\
\text { culture }\end{array}$ & Positive reflection \\
\hline & \multirow[t]{2}{*}{ Resuming gains } & $\begin{array}{l}\text { Considering as a means of } \\
\text { experience }\end{array}$ \\
\hline & & $\begin{array}{l}\text { Considering as a means of } \\
\text { development }\end{array}$ \\
\hline
\end{tabular}

When Table 2 is examined, it is observed that the categories and sub-categories (four categories and eleven sub-categories) in the second theme are more than the other themes. Here, it can be stated that the opinions expressed by the participants in the second theme were the source of the other themes and that the essence of the studies was the studies mentioned in this theme.

\section{Perception of school culture}

This theme consists of data obtained from 2 main questions and 4 probe questions. It is understood that the theme is divided into three categories within itself. These are the definition of school culture, differences in creating school culture and characteristics of school culture. 


\section{Definition of school culture}

This category also includes two categories. These are order and environment. The participants defined the school culture as the environment to be created for the effective and efficient working in achieving its goals, establishing order, and placing a certain discipline in the institution. In the definitions, it is seen that the values and the way of working are emphasized. The participants also linked the physical environment as well as the relaxed working environment to the school culture. The importance of communication in setting the appropriate environment and maintaining order-discipline has also been demonstrated. Opinions related to the subject can be stated as follows:

P2: School culture is commitment to school.

P5: School culture is the order of the school, the rules of the school, the peace of the school, and etc.

P7: It is the work carried out by the whole team in line with the same ideals.

P9: I think school culture is very important. School culture is the ability to do a job with discipline. School culture is order, authority, and everything.

\section{Differences in creating school culture}

This category also includes two categories. These are the working style and conditions. The participants stated that the differences in their schools in creating school culture are based on sharing with stakeholders and increasing the contribution of this to both academic and school. The common point in the differences is the specific studying style and conditions of each school. Opinions related to the subject can be stated as follows:

P1: There is good solidarity among the teachers, and I can see that.

P3: Our most important difference from other schools is to reflect the warm and friendly atmosphere to parents, teachers, and our students.

P6: For example, the relationship among the teachers in the school, the physical structure of the school, and the attitude and behavior of teachers towards parents...

P9: The school culture is settled in our school, and our friends are working in a friendly way. They are attracted to each other. This brings us the success, and the atmosphere of peace in the school is formed.

\section{Characteristics of school culture}


This category also includes two categories. These are values and communication. The participants evaluated the contributions to school culture more in relation to the environment. They express this as either turning the negative environment into a positive environment or maintaining the positive environment. They preferred to explain the characteristics of culture from the school environment they live in. These characteristics can be accepted as a combination of physical infrastructure, discipline, communication, and unity-solidarity based on these features in the studies and relationships. In addition, it is seen that being done in cooperation with parents is important in terms of both achieving the aim of education and doing things better and student-centered in unity-togetherness. Opinions related to this subject can be stated as follows:

P2: There must be trust, there must be loyalty to each other.

P3: Unity and solidarity of teachers and administrators, and sharing this with the family.

P6: The first of the characteristics of school culture is the relationship between employees.

P9: When there is a school culture, it is very important for the school culture to act together, to create a common goal, and to be willing for everyone when a project is made.

P11: In the institutions, the school principal cannot do anything alone. I see that the administration, parents, teachers, and students become more conscious in the school. We all have to work together.

\section{Creating school culture}

Three main questions and five probes were used in relation to this theme. Four categories were formed based on the data obtained. These categories are continuous studies in creating school culture, highlights in the school culture, the attitudes of employees in school culture, and facilitating and difficult factors in school culture.

\section{Continuous studies}

This category includes four categories within itself. These are communication with parents, organizing meetings, providing appropriate environment, and being role-models. Participants emphasize that parents have an important place in school culture, and they consider it important to reflect this to the studies in the school. In the studies with parents, both the contribution to 
the school and the works that can contribute to their development are reflected in the opinions. In addition, formal and informal meeting environments in the school draw attention as continuous studies in the context of school culture. Participants see and evaluate the meetings as a tool for both strengthening internal links and consensus. Ensuring the appropriate environment for the inclusion of parents and employees in the school culture is also among the practices that are carried out by the school administrators since the shaping of the environment in the desired direction arouses the opinion that school culture will also be formed in the desired direction. In order to do all this, it is important that school administrators become role-models for their stakeholders because the employees and other environmental elements can be affected by what the school administrators do and develop attitudes towards the school accordingly. The opinions for this subject can be stated as follows:

P1: I give importance to unity.

P2: First, the teacher should meet with friends to get ideas, and that is not imposed. There must be cooperation, as much as possible, each of my teacher friends has a feature, and I try to find it, touch it and then do the job.

P3: Obviously what we do is to invite the parent into the school.

P5: I care about myself, and I try to set an example.

P7: We are trying to bring our national and spiritual values to the forefront. We are trying to bring love, respect, justice, tolerance, and especially the SEDEP Project implemented by our Seljuk Municipality to the forefront.

P8: The indispensable thing was that the school administration had to be a role model. Their behavior has to set an example.

P9: We first started to do something and to increase self-confidence in the teacher. They've got these abilities. We have started to turn the prejudices in school into predictions.

\section{Highlights}

This category includes three categories in itself. These are being empathic, behaviors of administrators, and supportive approach. Participants emphasize being empathic, behaviors of administrators, and supportive approach as prominent points in the context of school culture. Empathic approach in creating school culture is considered important by the school administrators because the empathic approach determines the contribution to the school both inside and outside the school. Participation in the decisions of the school administration can directly affect the school environment, the quality of communication, and the commitment to 
the school. The behaviors of school administrators supporting this situation are considered important by the participants. Here, the most important point that draws attention in terms of school culture, as understood from the participants' views; is what the school administrator presents in terms of the personal and professional aspects. The opinions of the participants can be stated as follows:

P2: Initially, the teacher should meet with friends and get ideas of them, and that is not imposed.

P3: We try to do our work in a planned manner within the framework of respect and love.

P4: Rules. Both the unique rules of the school and the legal rules set by the legislation are very important. We share the legal rules very clearly with each of our staff and with our stakeholders.

P5: The most important issue in school culture is the principal. The principal determines peace, justice, gossip, communication, and cooperation in school. Care must be taken when choosing a principal.

P6: Communication among the stakeholders and satisfaction are very important. We are trying to put ourselves in the place of teachers, especially when making a curriculum. Our school has a misunderstood culture due to its environment. We're trying to eliminate this. We're working on the safety for the school.

P7: We are trying to bring our national and spiritual values to the forefront.

P9: The distribution of tasks is very important in school culture. It is easier for everyone to do a job than a person does every job.

\section{Attitudes of employees}

This category also includes two categories. These are positive and negative attitudes. The participants stated that, under the influence of the school administrator, the employees generally had positive attitudes towards school culture, and thus they observed behaviors towards contributing to the school culture. In general, it is understood from the opinions that the undesired attitudes are also encountered from time to time. In creating a school culture, the participants stated that the teacher is mainly in the center and that a school culture cannot be built without the support of the teacher. The opinions related to the subject can be stated as follows:

P3: Every teacher is in dialogue with every parent. The teacher comes to the school and meets with the parents, so the lessons are not interrupted, and there is a family atmosphere in the school. For example, I was very impressed with the fact that a teacher took care of a disabled student until the evening because 
of her hospital work, and that the teacher met with her parents so that the child could go to school.

P10: I believe that the teacher has more role in the formation and development of this culture than the principal. I would like to thank the teacher who contributed to the school culture in the teachers' board and classroom.

P11: The most important thing is that the teacher, the student, and the parents say this is my school. We are trying to highlight the activities that they feel the emotion of commitment to the institution. In addition, we aim to make them individuals with high academic achievement and basic religious and national knowledge.

\section{Factors affecting school culture}

This category also includes two categories within itself. These are parents and habits. The participants agree that the environment is both a facilitating and a challenging factor in creating a school culture. Considering the importance of parents and teachers in the context of school culture, the effect of the experiences can be better evaluated. It is understood that the studies to be carried out without the support of the teachers and parents will not contribute to the development of the school and will hinder the open system understanding mentioned in the administration literature. In addition to these factors, the participants emphasized that the existing habits are determinant when they come to the school where they work. Habits, like other factors, can be both facilitating and challenging. It is thought that these habits are one of the points that the school administrators should take into consideration in the formation of school culture. The related opinions can be stated as follows:

P2: The difficulty is always available. There is a habit. Because it is difficult to change the habit, it is actually his or her truth. You have to show him or her the truth itself, so he or she can give up his or her attitude.

P3: My teachers and my staff are the supporters for us.

P5: Some teachers are more supportive. Their support is very important.

P6: Of course there is. For example, there is a school culture, which is not easy to change. Most of our teachers support us in changing this culture, but we also have teachers and parents who do not. These are the problems that we usually encounter.

P7: We have just mentioned about the presence of a team. In that sense, if the team is insufficient, it is a problem.

P11: The wrong habits obtained in other schools, teachers, administrators, parents, or not participating in the teamwork have negative effects. 


\section{Project-based studies}

Data on this theme were obtained from three main and five probe questions. It is understood that three categories emerged based on the data. These are the projects, the objectives of the projects, and the evaluation of the projects.

\section{Projects}

This category also includes two categories within itself. These are processes and content. The participants demonstrate that the project process is both laborious, troublesome and exciting and pleasing. The point that draws attention in the point of projects is that the participants try to carry out the projects closely both in and out of school, inside and outside the region, both in the country and abroad, and try to adopt the mentioned working style as a school culture. Here, it is emphasized that the studies should be carried out with the understanding of teamwork. The opinions of the participants can be stated as follows:

P4: In addition to the project-based school academic education, we are trying to create a brain-centered structure, since the social sciences, where human beings are social entities, are also prone to such a project. Therefore, TÜBITAK and European Union projects are very important for us and we are trying to associate each student with a project. We care about each contest. We try to motivate and raise the awareness of teachers and students and involve them in this work.

P5: We have a project called "Become Family with Books" in our school. KPP (Konya Plain Project) supports this. We have "The Cleanest Class" project. In addition, we participate in projects carried out in the district.

P10: All the projects of our school are on three stages. The first one is "human first, education first". We want to raise our children as good people, not as knowledge monsters. We act according to "Sensitive Family, Virtuous Child" and "Every Child is Special" approach. In our classrooms, we do reading activity for 15 minutes every day.

\section{Objectives in the projects}

This category includes four categories within itself. These are correcting negative behaviors, the need for project studies, active participation in activities, and gaining values. It is understood that the expectations of the participants from the project studies are high. It is noteworthy that they deal with the projects both in educational and instructional dimensions, as well as covering the lives of students outside the school. It is understood that all these elements make the school a habitable and willing place for all stakeholders, especially students, 
and contribute to the image of the school. Some examples related to the opinions of the participants can be stated as follows:

P1: We have seen that if our teachers are willingly attending the meetings, seminars and the projects, the productivity increases there.

P2: In the solution of the problems, a consensus can be provided, and the wrongs can be seen, and the truths can be revealed. As a project, everything is for us, for a livable future...

P5: Reading books is the basis of education. If a person doesn't read or doesn't understand what he reads, we can't tell him any lessons.

P9: We disrupt the education part of children. We want to educate good people in line with the curriculum. We also think that projects can contribute to education. We do it so that they can think freely, develop their self-confidence and develop their imagination.

P10: We think that all of our projects should be in the interest of human, children, and community. We want to keep them alive at school.

P11: Our goal is to raise our children in accordance with national spiritual values, to increase the academic achievement of our children, to ensure that they understand the basic religious values in the best way, to train individuals who fulfill their responsibilities in social life, and to obtain educational gains.

\section{Evaluation of projects}

This category also includes two categories within itself. These are emotional effect and contribution to school culture. The participants stressed that the project process was troubled and exciting but that all these experiences turned into happiness at the end of the project. Positive feedback is received from the projects, and the project process is considered as an important step towards strengthening the school culture because it is believed that the projects benefit to the school, students, parents, and teachers. It is understood that the participants attach importance to two points in the project studies. The first one is convincing the team members and thus providing support to the project to be carried out, and the second is that they believe that the projects can achieve their goals through teamwork and try to implement this. The related opinions can be stated as follows:

P1: Preparing projects and taking part in projects is a bit troublesome. A few people take on the tasks, and therefore these people get crushed because of taking over and do not want to participate in the studies to be done later. We made a nice sharing between ourselves, and everyone added something.

P4: It's about loving. If a person loves something, he or she becomes motivated. People like to do what they love. So, we do this with volunteer groups. We are 
trying to create the infrastructure for someone to volunteer for this. Sometimes, there are complaints about it. Fr example, I couldn't be in that group. Will a new group be opened?

P5: We start the project with excitement. We are experiencing some difficulties during the project.

P7: For example, when we started SEDEP, some of our friends opposed us. We explained this project to our teachers and parents. Everything happens when they believe.

\section{Project-school culture relationship}

Data on this theme were obtained from two main and two probe questions. It is understood that two categories emerged based on the data. These are the reflections of the projects on the school culture and resuming the gains.

\section{Reflections of projects on school culture}

This category also includes a category within itself. It is positive reflection. It is understood that the participants agreed that the projects had a positive effect on the school culture. It is reflected in the opinions that the projects contribute to gaining positive behaviors to students, providing unity and solidarity, and increasing commitment to the school and harmony. It is emphasized that the positive reflections will be the pioneer of changes and developments in the desired direction in school culture. Opinions of some participants can be stated as follows:

P1: In each of our projects, we have seen that our students and parents have significantly increased their contribution to the school. We have seen that we will bring our students to school through the projects and activities.

P4: Of course, it further strengthens the culture and increases our ties with each other. We get the opportunity to get to know each other closely. With the motivation and excitement of doing the tasks, the staff is better known. They are better committed to school culture. The main concept here is the commitment. On this occasion, the compliance of the staff is increasing. Ties are getting strengthened. The competition is based on very sweet rivalry.

P5: Negative behaviors decrease.

P6: These projects affect all stakeholders in terms of school culture. The projectbased activities led to the formation of team spirit in the school culture, increasing the desire of the students to come to the school, and increasing the trust of the parents to the school.

P7: For example, consider the value of "respect". We did it with the kids. The students do not run out of class. They know they can hurt their friends while 
they run. They take care of their speaking to the elders. These are our observations.

\section{Resuming gains}

This category also includes two categories in itself. These are considering as a means of experience and considering as a means of development. The participants see what is happening in terms of resuming gains both as an experience -individually and professionally- and development, and they consider it appropriate to continue the enrichment in terms of both quality and quantity. They also care about the spread of what is happening to the environment. The opinions related to the subject can be stated as follows:

P2: We will ensure continuity.

P4: I think our biggest achievement is the students we graduate. We believe that they will progress much better in their social life.

P8: We definitely share our activities with the people around us. We share everything with the county and provincial national education directorate. We invite them, and we tell them what we can do. We are trying to present our sensitivity.

P9: We plan to have a different activity every year. We do not want the education to be interrupted. We continue the projects we started last year. This year, we added new ones.

P10: We want to be an effective school until the student's decision to get married. In doing so, we want to involve our parents in the process. We want the school to be with the family, not just with the child, and we are working on this.

P11: We must continue our work. We will continue to give importance to consultation. We need to change what we believe is not useful. We will struggle to continue the gains.

\section{Data obtained from Observations}

The observations, which are based on the teaching and school administration experiences of the researchers and which are expected to be made by paying attention to the situations stated by Merriam (2014), include five points. These are the opinions of the researchers about the participants, the attitudes of the participants towards the research and the researchers, the examples of the participants embodying their opinions, the schools and the principal rooms where the interviews were carried out, and other remarkable points that may contribute to the research.

According to the observations of the researchers, the participants provide various activities and practices in the schools where they work. These activities are both in the study schedule of the school and added by the teachers' board to the study schedule of the school. It is thought that it is decisive for P8 to express his satisfaction by sharing one of his activities with the 
participants in the award ceremony. Although there is a different number and quality of activities in each school visited, an activity and project-based school culture is in the effort to be placed in the school. While it is expected that all schools will continue their activities within the framework of the same legislation, the differences in the number and variety of activities in each school are thought to be directly related to the attitude of school principals according to the professional observations of the researchers. However, despite the differences in all schools, it was observed that they were in an effort and search. These observations are considered important by the researchers in terms of showing that the project and activity based approach mentioned in the interviews are being tried to be implemented.

It is thought that meeting with the researchers and meeting them in a hospitable manner, giving clear and sincere answers to the questions are determinant in reaching the purpose of the research. It is thought that this was due to the fact that the researchers and participants were colleagues and personal acquaintances. The positive communication between the researcher and the participant provides a confidence in expressing opinions. Furthermore, the fact that the participants stated that they wanted to be informed about the results of the research and that they did not answer the phone calls during the interview gave a positive communication between the researcher and the participant. These cases indicate that the interviews were conducted in accordance with the purpose of the research.

The participants presented their opinions not only verbally but also through the records they kept on the computer. In addition, the announcements and formal writing examples of various studies and procedures were seen on the boards of the rooms of participants and in the teachers' room. In addition to this, writings and visuals related to the studies carried out were also found in the corridors and in the classrooms. However, whereas the administrative practices and documents (teacher club distribution, list of on-duty teachers, etc.) were observed in the executive rooms and teachers' rooms, the practices and documents related to activities and projects (book reading contest announcement, TÜBITAK project competition etc.) were available in the corridors and classrooms. In addition, the showcases showing the successes of the activities were found in the corridors and in the principal room. All these indicate that both activity-based and administration-based practices are tried to be completed together and complementary in schools. 
It was observed that the schools and administrative rooms were clean and suitable for education and training. The fact that the staff of the school was trying to clean the whole school in two of the schools attended for the interview supports this idea. In addition, the presence of flowers in the administrator room and the teachers' room evoked the opinion that the tasks were done in a comfortable environment.

In general, participants strive to create a project-oriented school culture. The fact that they are willing to explain what they have done in their schools and their efforts willingly, share the activities and the visuals about the gains made as a result of these activities, show the school themselves to the researchers, and explain the situation supports the interview data obtained in the research.

\section{Conclusion, Discussion, and Recommendations}

In this qualitative research carried out with eleven principals, the following conclusions have been obtained by the researchers: School culture is taken into consideration to provide a suitable environment for the educational activities and to conduct a certain order. In the school culture, the socio-economic situation of the schools, the attitudes of the parents and the perspectives of the administrators are the determinants of building of values and the spread of healthy communication. Project studies are considered as very important in the schools. It is understood that the project-based studies show a proximodistal character, both in and out of school, in and out of the region, in and out of the country. It is also concluded that there are various gains from the projects. These are to ensure that the desired behaviors are put into practice by keeping the students away from the problems they may experience, to meet the need to provide working discipline and to realize this, and to internalize the values (love, respect, sense of responsibility, etc.) that are tried to be given in the school through the studies that the project team will actively participate in. All projects have an individual and professional contribution to both the school and the project team. The projects have a positive effect on the school culture. The individual reflection of the positive effect is to give the participants an experience with all their processes. In the professional sense, it contributes to the development of the school and the project team since it contributes to the studies carried out in the school and provides a learning environment. In this study, which is generally based 
on school culture and in particular on the project-based studies, it was observed that the importance of school culture and the attempt to bring it to life through various activities such as projects are indispensable for the development of both the school and the stakeholders. This observation coincides with the findings carried out by Stanford (2014); Bower and Parsons (2016); and Parwazalam, Syed Kamaruzaman, Aliza, Nor Afizah (2014) about the fact that the school culture will contribute to the employees, as well as the motivation of the contribution to the organization and that all these developments will contribute to the school culture in parallel with this increase in success. The conclusion that the school administrators play an important role in maintaining a healthy existence in terms of creating school culture is also observed in the result of the studies conducted by Küçükali (2011); Melesse and Molla (2018); and Ohlson, Swanson, Adams-Manning, Byrd (2016). According to the researchers, a good education administrator takes the opinions of the teacher into consideration. He or she makes efforts to make the teacher happy at school. The administrator creates a school culture based on development through various studies including academic achievement. The relationship between school culture and school administrator has also been examined by Fitzhenry (2010); and Sabanc1, Sönmez, Şahin and Y1lmaz (2017). According to the results of the research, the principals have an important role and contribution to school culture. This result is thought to be similar to the conclusion in the current research that the school administrators should be a role model in school culture. It is also thought that the result that the project-based studies provide various benefits to the project team is in line with the research finding in the study carried out by Y1lmaz (2017) that the project studies contribute to the problem-solving ability of the students. In addition, the conclusion that the attitudes of school administrators are important in creating a project-based school culture coincides with the research findings obtained in the studies carried out by Yaşar (2015); and Carroll, Fulmer, Sobel, Garrison-Wade, Aragon and Coval (2011) that the support of the school administration is also important for the success of students in their studies.

Based on the research, the followings can be recommended for practitioners: School administrators can focus on project-based studies in building school culture. What is obtained from the projects can be shared with those who are willing to do the project but need guidance on how to do it. The efforts to create a project-based culture can be supported. Project training seminars can be organized for the teams for project-based studies. Project examples can be shared with the institutions that are stakeholders in education. For the researchers, the 
followings can be proposed: The current research topic can be developed and explored by including the other stakeholders in the school. The topic of the research can be discussed by using different research methods. Since there is not enough research in the literature regarding the relationship among the school culture, project studies, and principals, some other further research can be done by examining this relationship. 


\section{References}

Akıllı, C. (2017). Proje döngüsü yönetim aşamaları açısından öğretmen ve yöneticilerin hazırladıkları ve yürüttükleri eğitim projelerinde karşılaşılan sorunlar (Elazı̆̆ ili örneği) (Yayınlanmamış yüksek lisans tezi). Fırat Üniversitesi, Eğitim Bilimleri Enstitüsü, Elazığ.

Bayrakc1, M. (2014). Okul kültüründe değişimin yönetimi. İçinde, N. Güçlü (Ed.). Okul kültürü içinde (s. 181-204). Ankara: PegemA.

Bower, H. A., \& Parsons, E.R.C. (2016). Teacher identity and reform: intersections within school culture. Urban Rev, 48:743-765, doi: 10.1007/s11256-016-0376-7

Börekci, C. (2018). Proje tabanlı öğrenme ile öğrenenlerin özdüzenleme ve üstbiliş becerilerinin desteklenmesi (Yayınlanmamış yüksek lisans tezi). Balıkesir Üniversitesi, Sosyal Bilimler Enstitüsü, Balıkesir.

Carroll, D., Fulmer, C., Sobel, D., Garrison-Wade, D., Aragon, L., \& Coval, L. (2011). School culture for students with significant support needs: Belonging is not enough international. Journal of Special Education, 26(2), p. 120-127.

Cameron, K.S., \& Quinn, R.E. (2017). Örgüt kültürü örgütsel tanı ve değişim (M. G. Gülcan, N. Cemaloğlu, Çev. Ed.). Örgüt kültürünü değiştirmeye genel bakış, (D. Koşar, Çev.) Ankara: PegemA.

Christensen, L.B., Johnson, R.B., \& Turner, L.A. (2015). Nitel ve karma yöntem araştırmaları (M. Sever, Çev.), (A. Aypay, Çev. Ed.) Araştırma yöntemleri desen ve analiz içinde (s. 400-433). Ankara: An1.

Creswell, J.W. (2016). Nitel araştırma tasarımı. A. Budak ve İ. Budak, (Çev.), M. Bütün ve S. B. Demir, (Çev. Ed.), Nitel araştırma desenleri içinde (s. 42-68). Ankara: Siyasal.

Çevik, A., \& Köse, A. (2017). Öğretmenlerin okul kültürü algıları ile motivasyonları arasındaki ilişkinin incelemesi. Insan ve Toplum Bilimleri Araştırmaları Dergisi, 6(2), s. 996-1014.

Deal, T. E., \& Peterson, K. D. (1990). The principal's role in shaping school culture. U.S. Department of Education Office of Educational Research and Improvement, ERIC Number: ED325914.

Engels, N., Hotton, G., Devos, G., BouckenoogheD., \& Aelterman, A. (2008). Principals in schools with a positive culture. Educational Studies, 34(3), s. 159-174. 
Fitzhenry, K.M. (2010). Perceptions of school culture: influences on high school teachers' choice of pedagogy. (Doctoral dissertation) Retrieved from ProQuest Dissertationsand Theses (UMI No. 3435596).

Fourie, E. (2018). The impact of school principals on implementing effective teaching and learning practices, International Journal of Educational Management, 32(6), 1056-1069, doi: 10.1108/IJEM-08-2017-0197.

Glesne, C. (2015). Nitel araştırmaya giriş. A. Ersoy, (Çev.), A. Ersoy ve P. Yalçınoğlu, (Çev. Ed.), Öykünüzü keşfetmek: veri analizi (s. 255-300). Ankara: An1.

Hindle, T. (2014). Yönetimde çı̆̆ır açan gurular (Ü. Şensoy, Çev.). İstanbul: Türkiye İş Bankas1 Yayınları.

Hofstede, G., Neuijen, B., Ohayv, D. D., \& Sanders, G. (1990). Measuring organizational cultures: a qualitative and quantitative study across twenty cases. Administrative Science Quarterly, 35(2), s. 286-316.

Hoy, W.K., \& Miskel, C. G. (2010). Okullarda kültür ve iklim. (M. Şişman, Ş. Uysal, Çev.), S.Turan (Çev. Ed.), Eğitim yönetimi: teori, araştırma ve uygulama (s. 163-201). Ankara: Nobel.

Karadeniz, O. (2012). Sosyal bilgiler proje fuarının sosyal bilgiler dersine ilişkin tutumlara etkisi ve sürece yönelik ögrenci, öğretmen ve veli görüşleri (Yayınlanmamış doktora tezi). Gazi Üniversitesi, Eğitim Bilimleri Enstitüsü, Ankara.

Karakuş, M. (2004). İlkögrretim dördüncü sınıf sosyal bilgiler dersinde proje yaklaşımlı öğretimin öğrencilerin sorun çözme becerilerine tutumlarına akademik başarılarına kalıcılığına etkisi (Yayınlanmamış doktora tezi). Çukurova Üniversitesi, Sosyal Bilimler Enstitüsü, Adana.

Ketterlin-Geller, L.R., Baumer, P., \& Lichon, K. (2015). Administrators as advocates for teacher collaboration. Intervention in School and Clinic, 51(1), s. 51-57, doi: $10.1177 / 1053451214542044$

Kocaarslan, M. (2010). İlköğretimde görev yapan öğretmenlerin tamamlayıcı bir değerlendirme aracı olan proje görevlerine ilişkin görüşlerinin değerlendirilmesi (Bitlis ili örneği) (Yayınlanmamış doktora tezi). Yüzüncü Yıl Üniversitesi, Sosyal Bilimler Enstitüsü, Van.

Kraft, M.A., Marinell, W.H., \& Shen-Wei Yee, D. (2016). School organizational contexts, teacher turnover, and student achievement: evidence from panel data. American Educational Research Journal, 53(5), s. 1411-1449, doi: 10.3102/0002831216667478

Krippendorff, K. (2004). Content analysis. London: Sage publications.

Küçükali, R. (2011). Yönetim felsefesi. Ankara: Nobel. 
McEwan, E.K. (2018). Etkili okul yöneticilerinin on özelliği (N. Cemaloğlu, Çev. Ed.). Ankara: PegemA.

Mees, G.W. (2008). The relationships among principal leadership, school culture, and student achievement in Missour middle schools. (Doctoral dissertation) Retrieved from ProQuest Dissertationsand Theses (UMI No. 3371083).

Melesse, S., \& Molla, S. (2018). The contribution of school culture to students' academic achievement: the case of secondary and preparatory schools of assosa zone, benshangul gumuz regional state, Ethiopia. Research in Pedagogy, 8(2), p. 190-203.

Merriam, S.B. (2015a). Araştırmanın desenlenmesi ve örneklem seçimi (S. Turan, ve D. Yılmaz, Çev.), S. Turan (Çev. Ed.). Nitel araştırma desen ve uygulama için bir rehber içinde (s. 55-82). Ankara: Nobel.

Merriam, S.B. (2015b). Görüşmelerin etkin yönetimi (S. Turan, Çev.), S. Turan (Çev. Ed.). Nitel araştırma desen ve uygulama için bir rehber içinde (s. 85-110). Ankara: Nobel.

Merriam, S. B. (2015c). Nitel araştırma desen ve uygulama için bir rehber (H. Özen, M. Yalçın, Çev.), (S. Turan, Çev. Ed.). Dikkatli bir gözlemci olmak içinde (s. 111-131). Ankara: Nobel.

Miles, M.B. ve Huberman A.M. (2015). Veri toplamaya odaklanmak ve veri toplamayı sinırlamak: anlamlı bir başlangıç (D. Örücü, Çev.), (S. Akbaba Altun, A. Ersoy, Çev. Ed.) Nitel veri analizi içinde (s. 16-39). Ankara: PegemA.

Milli Eğitim Bakanlı̆̆ı (MEB). (1973). Milli eğitim temel kanunu. Erişim adresi: http://www.meb.gov.tr/mevzuat/liste.php?ara=2.

Milli Eğitim Bakanlı̆̆1 (MEB). (2014). Milli eğitim bakanlı̆̆l okul öncesi eğitim ve ilköğretim kurumları yönetmeliği (temel eğitim genel müdürlüğ̈̈). Erişim adresi: http://www.meb.gov.tr/mevzuat/liste.php?ara=6

Milli Eğitim Bakanlığı (MEB). (2013). Milli ę̆itim bakanlı̆̆l ortä̈ğretim kurumları yönetmeliğ (ortaögretim genel müdürlüğ̈̈). Erişim adresi: http://www.meb.gov.tr/mevzuat/liste.php?ara=6

Milli Eğitim Bakanlığı (MEB). (2017). Millî eğitim bakanlı̆̆ı ĕgitim kurumları sosyal etkinlikler yönetmeliği. Erişim adresi: http://www.meb.gov.tr/mevzuat/liste.php?ara=6

Neuman, L.W. (2010). Toplumsal araştırma yöntemleri, (S. Özge, Çev.). İstanbul: Yayın Odası.

Ohlson, M., Swanson, A., Adams-Manning, A., \& Byrd, A. (2016). A culture of success-examining school culture and student outcomes via a performance framework. Journal of Education and Learning; 5(1), p. 114-127, ISSN 1927-5250. 
Parwazalam, A., Syed Kamaruzaman, S., Aliza A., \& Nor Afizah, M. (2014). The effect of school culture on the management of professional development in secondary schools in Malaysia. The Malaysian Online Journal of Educational Science, 2(3), s. 41-52.

Patton, M. Q. (2014). Nitel araştırma tasarımı. B. Tarman ve M. F. Yiğit, (Çev.), M. Bütün, S. B. Demir (Çev. Ed.), Nitel araştırma ve değerlendirme yöntemleri içinde (s. 209-258). Ankara: Pegem A.

Renchler, R. (1992). Student motivation, school culture, and academic achievement. ERIC Clearinghouse on Educational Management University of Oregon, Book Number 0-86552116- 6.

Sabanc1, A., Şahin, A., Sönmez, M.A., \& Yılmaz, O. (2017). Views of school managers and teachers about school culture. E-International Journal of Educational Research, 8(1), p. 28-45, doi: $10.19160 / 5000186332$.

Savory, E.P. (2014). Perceptions of leadership characteristics of principals who influence positive school culture in a Midwest Adventist union: a qualitative study (Doctoral dissertation) Retrieved from ProQuest Dissertations and Theses (UMI No. 3626217).

Schein, E.H. (1984). Coming to a new awareness of organizational culture. Sloan Management Review, 25(2), s. 3-16.

Stanford, N. (2014). Organizasyon kültürü (Ü. Şensoy, Çev.). İstanbul: Türkiye İş Bankası Yayınları.

Şimşek, Y. (2003). Okul müdürlerinin iletişim becerileri ile okul kültürü arasındaki ilişki (Yayınlanmamış doktora tezi). Anadolu Üniversitesi, Eğitim Bilimleri Enstitüsü, Eskişehir.

Şişman, M. (2002). Örgütler ve kültürler. Ankara: Pegem A.

Türk Dil Kurumu (TDK). (2019). Kültür. Erişim adresi: https://sozluk.gov.tr/

Türk Dil Kurumu (TDK). (2019). Örgüt kültürü. Erişim adresi: https://sozluk.gov.tr/

Türk Dil Kurumu (TDK). (2019). Proje. Erişim adresi: https://sozluk.gov.tr/

Türkiye Cumhuriyeti Anayasası. (1982). Erişim adresi:

http://www.meb.gov.tr/mevzuat/liste.php?ara=12

Yaşar, N. (2015). Coğrafya öğretmenlerinin proje hazırlama ve yönetme sürecine ilişkin görüşleri (Yayınlanmamış yüksek lisans tezi). Gazi Üniversitesi, Eğitim Bilimleri Enstitüsü, Ankara.

Yıldırım, A., \& Şimşek, H. (2011). Sosyal bilimlerde nitel araştırma yöntemleri. Ankara: Seçkin.

Y1lmaz, M. (2017). Illköğretim öğrencilerinin proje tabanlı öğrenme modeline dayalı güvenli internet kullanımı uygulamalarının değerlendirilmesi - Hollandalı ögrencilerle bir eylem araştırması(Yayınlanmamış yüksek lisans tezi). Marmara Üniversitesi, Eğitim Bilimleri Enstitüsü, İstanbul. 
Wagner, A.T. Harrison C., \& Vogel, L.C. (2016). Cultures of learning in effective high schools. Educational Administration Quarterly, 52(4), 602-642, doi: 10.1177/0013161X16644957.

Westhuizen, P.C.V., Mosoge, M. J., Swanepoel, L. H., \& Coetsee, L. D. (2005). Organizational culture and academic achievement in secondary schools. Education And Urban Society, 38(1), 89-109. doi: 10.1177/0013124505279959.

Zelyurt, H. (2011). İlköğretim okullarında uygulanan proje ve performans görevlerinin etkililiğinin değerlendirilmesi (Malatya ili örneği) (Yayınlanmamış doktora tezi). Fırat Üniversitesi, Sosyal Bilimler Enstitüsü, Elazı ̆. 